\title{
EMBRACING ENTREPRENEURIAL CHANGE: ENTERPRISING IN YEMEN COMPARED WITH OTHER LEAST DEVELOPED COUNTRIES
}

\author{
Mugaahed Abdu Kaid Saleh ${ }^{1}$ (D) Manjunath K.R. ${ }^{2}$ (D) \\ ${ }^{1} \mathrm{Ph} . \mathrm{D}$. Scholar, Department of Management, Kuvempu University, India. \\ ${ }^{2}$ Associate Professor, Department of Management, Kuvempu University, India.
}

\section{ARTICLE INFO}

Received: 29 August 2021

Revised: 10 October 2021

Accepted: 24 October 2021

Keywords:

Enterprising, Entrepreneurship,

SMEs, Doing business,

Development, LDCs, Yemen.

Corresponding Author: Mugaahed Abdu Kaid Saleh

Email: mugaahed@yahoo.com

Copyright () 2021 by author(s) and Journal of Scientific Research in Medical and Biological Sciences. This work is licensed under the Creative Commons Attribution International License (CC BY 4.0). http://creativecommons.org/licenses/ by/4.0/
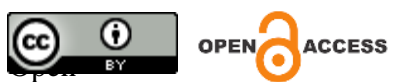

\begin{abstract}
Purpose: The stud aims to compare the status of entrepreneurship activities and the encouragement of entrepreneurship in the five least-developed countries: Afghanistan, Bangladesh, Rwanda, Sudan, and Yemen.

Approach/Methodology/Design: A comparative method is adopted, a comparison of the status of entrepreneurship among five different least developed countries (Afghanistan, Bangladesh, Rwanda, Sudan, and Yemen). By relying on secondary data, with the help of tabulation and visualization of the data, four main variables are used to compare entrepreneurship in these countries (Definition, development, obstacles, and reforms).

Findings: The results showed that the least developed countries do not pay much attention to the sector of SMEs as a crucial sector for economic development. Among the five countries, Rwanda is found to be the reference point in achieving remarkable development in the aspect of entrepreneurial development.

Practical Implications: Based on the different experiences examined in the study, a model of the key drivers of entrepreneurial change is suggested. It would act as a roadmap to drive the economy towards achieving entrepreneurial change as in the case of Rwanda.

Originality/value: The study proposes a model for embracing entrepreneurial change which can be tested and validated in further research work. The study also attempts to attract the attention of policymakers and international development partners towards the importance of encouraging entrepreneurship activities in the least developed countries.
\end{abstract}

\section{INTRODUCTION}

Entrepreneurship has driven the attention of economists, policymakers, researchers, scholars, and managers as being one of the core aspects of the dynamics of capitalism (Baumol, 1993). The misquotation of Wilson, "What's good for General Motors is good for America" whether true or was just derided endlessly as a joke of a slogan highlighted the emergence of big manufacturing activities in the automobile sector (Audretsch, 2009). Entrepreneurship and small business barely existed in academic programs and graduate schools during the 1970s 
(Acs, Audretsch \& Strom, 2009); which offlate has found its significance/importance in research articles investigating entrepreneurship (Volery \& Mazzarol, 2015).

Emerging economies for a long era have been exposed to foreign domination, facing institutional inefficiencies as well as extensive state intervention (Austin, Dávila \& Jones, 2017). After the collapse of the Soviet Union and the transformation of centralized economies into market economies, attention has been paid towards development of small and medium enterprises (as a base) for development in emerging economies (Ács \& Virgill, 2009), as entrepreneurship being highlighted as a key factor for economic development. Schumpeter's work on economic development and entrepreneurship (1934), has been one of the most widely cited research in the literatures of management discipline (Bruton, Ahlstrom \& Obloj, 2008), especially due to its role identified in the process of economic growth and transition among developing as well as developed countries.

Entrepreneurship is becoming a global phenomenon (Smallbone, Welter \& Ateljevic, 2014), regardless of the variance of nature, extent and contribution of entrepreneurship from one country to another; especially, in cultural and institutional contexts (Bruton, Ahlstrom \& Obloj, 2008). The Global Entrepreneurship Monitor (Reynolds, et. al., 2003) indicated that around 400 million individuals are managers or owners of newly established enterprises among developing countries, indicating the association of entrepreneurship with wealth and poverty in developing economies. Further, investments in entrepreneurial activities by youth is higher in developing countries than in developed countries, as the barriers to entry especially in the informal sector is very low (Aidis, Estrin \& Mickiewicz, 2007).

Evaluating the differences in entrepreneurial activities among countries, it is learned that where "opportunity entrepreneurs" are more common in high-income countries, "necessity entrepreneurs" are more common in low-income countries (Acs, Desai \& Hessels, 2008; Baumol, 1990); this implies that necessity entrepreneurs are supposed to be even more common in lower-income countries or least developed countries. The emergence of 'productive entrepreneurship' and the structural transformation has accelerated economic growth and created jobs in the least developed countries, and has facilitated to drive out poverty and realize inclusive development in convergence with other economies (Brixiova, 2010).

Encouraging entrepreneurial activities among small and medium enterprises in the least developed countries play a key role in achieving inclusive development and economic welfare. However, a scant amount of literate exists when considering least developed economies and the encouragement towards small and medium enterprises. The differences in entrepreneurship activities existing among least developed countries, and need for conducting a comparative study to compare enterprising activities in Yemen to those in other least developed countries; and to have insight into such differences among these countries and explore what is the effective model to adopt and accelerate enterprising and realize development goals related to the SMEs sector in Yemen, the following study is initiated.

\section{LITERATURE REVIEW}

The Committee for Development Policy at the United Nations employs three criteria to review the list of least developed countries every three years - which reviews whether to add countries to the list or to declare a country's graduation from the list. The three criteria are per capita 
income, human assets, and economic vulnerability. A country gets added to the list of least developed countries where it meets the addition thresholds; based on, the above-mentioned criteria, and after the consent of its Government, and with a population not greater than 75 million. On the other hand, a country can graduate when meeting the graduation thresholds based on at least two of the three criteria during at least two consecutive triennial reviews by the committee. Examples of the countries that have graduated the least developed countries list include Botswana which graduated the list in 1994, Cabo Verde in 2007, the Maldives in 2011, Samoa in 2014, and Equatorial Guinea in 2017 (United Nations, 2019).

The five countries constituting this study (Afghanistan, Bangladesh, Rwanda, Sudan, and Yemen) are lower-income and underdeveloped countries. However, they still differ from each other in respect of many details and statistics which are very interesting for comparison and providing meaningful insights into the enterprising processes and activities present in these economies. Afghanistan is a landlocked country in South Asia, with an area of 652,230 square kilometers. Its capital city is Kabul with a total population of around 34 million. $21.8 \%$ of whom are in the age group of 15-24 years, while 30.6\% are in the age group of 25-54 years. The density of population is 60 people per square kilometer. GDP per capita is USD 2,000, and an income per capita of USD 2,000. Afghanistan is divided administratively into 34 provinces (CIA, 2018). The major cities are Kabul with a population of 5,266,000, Kandahar with a population of 557,118 , Herat with a population of 436,300 , and Mazar-i-Sharif with a population of 368,100 (CSO, 2018).

Bangladesh is a country in South Asia, Dhaka being its capital city. Bangladesh with a total area of 148,460 square kilometers, has a population of 159,453,001. 40.07\% of its population are in the age group of 25-54 years, $19.14 \%$ are in the age group of 15-24 years. The density of population is 1115 people per square kilometer, with a per capita income of USD 4,200. Bangladesh is divided into 8 different divisions, and each division is named after the major city, which is further divided into several districts called Upazilas. Major cities are Chittagong, Rajshahi, and Khulna. Bangladesh has a Per capita income of USD 4,200 (CIA, 2018).

Rwanda is one of the smallest countries in Africa neighboring the Congo republic, Uganda, Tanzania, and Burundi, with a total area of 26,338 square kilometers, has a population of $12,187,400.19 .45 \%$ of them are in the age group of $15-24$ years, while $40.07 \%$ are in the age group of 25-54 years. The density of population is 525 people per square kilometer, with income per capita of USD 2,100. The capital of Rwanda is Kigali which is also the largest city and a center for cultural, economic and transport hub since the 1960s (CIA, 2018).

Sudan, an Arab country in Africa is boarded by Egypt, South Sudan, and Chad. Its population is $43,120,843$ with a population density of 25 people per square kilometer. $29.8 \%$ of its population are in the age group of 25-54 years, 20.22\% are in the age group of 15-24 years, with a per capita income of USD 4,300. Khartoum is the capital city of Sudan which is the largest city in Sudan with a population of 5,274,321 and is the sixth-largest city in Africa. Sudan is divided into 18 divisions or states and further divided into 133 districts (CIA, 2018). Yemen, located in the Southwest of Asia, is neighbored by Oman and Saudi Arabia. It is considered to be the poorest country in the Middle East and North Africa (MENA) (World Bank, 2015a) with a population of $28,667,230$, with a total area of 527,968 square kilometers. The density of population is 52 people per kilometer. $21.26 \%$ of its population are in the age 
group of 15-24 years, 32.78\% are in the age group of 25-54 years, with income per capita of USD 2,500 (CIA, 2018). Yemen is divided into 22 Governorates, every governorate is divided into districts. Sana'a is the capital city of Yemen and Aden is its economic center. The summary of these economies is presented in the table below.

\begin{tabular}{|c|c|c|c|c|c|c|c|}
\hline Country & Capital & $\begin{array}{c}\text { Area } \\
\mathrm{km})\end{array}$ & Population & Density & $\begin{array}{c}\text { Population } \\
\text { at } 15-24 \text { years }\end{array}$ & $\begin{array}{l}\text { Population at } \\
\text { age } 25-54 \text { years }\end{array}$ & $\begin{array}{c}\text { GDP - per } \\
\text { capita (PPP) }\end{array}$ \\
\hline Afghanistan & Kabul & 652,230 & $34,940,837$ & 60 & $21.85 \%$ & $30.68 \%$ & $\$ 2,000$ \\
\hline Bangladesh & Dhaka & 148,460 & $159,453,001$ & 1115 & $19.14 \%$ & $40.07 \%$ & $\$ 4,200$ \\
\hline Rwanda & Kigali & 26,338 & $12,187,400$ & 525 & $19.45 \%$ & $32.93 \%$ & $\$ 2,100$ \\
\hline Sudan & Khartoum & $1,861,484$ & $43,120,843$ & 25 & $20.22 \%$ & $29.8 \%$ & $\$ 4,300$ \\
\hline Yemen & Sana'a & 527,968 & $28,667,230$ & 52 & $21.26 \%$ & $32.78 \%$ & $\$ 2,500$ \\
\hline
\end{tabular}

Table 1: Statistics about five least developed countries.

Source: (CIA, 2018).

\section{METHODOLOGY AND PROCEDURES}

The study is a comparative' presenting a comparison of entrepreneurship activities in five least developed countries (LDCs) -Afghanistan, Bangladesh, Rwanda, Sudan, and Yemen, aiming to provide a comprehensive insight into the process of enterprising in these LDCs, and aims to explore those best experiences that Yemen can adopt to attain objectives of economic growth and welfare.

It is a multi-stage study which is undertaken in three stages; a) to conduct a comparative study of five countries and understand the nature of SMEs, their definition and their contribution; $b$ ) the factors that promote business in these economies and; c) the nature of hindrance and obstacles faced by SMEs and the reform measures initiated by them to oversee those hindrances/obstacles.

- The first stage focuses on reviewing the definition adopted for SMEs in these economies and their contribution to the economy on the existing literature and secondary data (publicly available).

- The second stage focuses on the investigation of the factors that lead to the development of business based on the ranks and progress of these economies with the help of analysis of the data provided by the World Bank about for the period 2009 - 2019, and have a comparative overview of the countries' performance in enterprising during the last decade.

- The third stage of research focuses on the nature of obstacles and challenges faced by SMEs and the reform measures initiated in these economies with the help of the enterprise survey database and Doing business database by the World Bank, and explore measures for adoption by Yemen from the beneficial experience of these countries with regard to reforming the business environment as well as encountering obstacles that are faced by enterprising activities in these countries.

To be in a position of gaining an insight into the differences in the business indexes and matrix in every country during the last ten years, coupled with the differences of the same among the five countries included in the study, the study relied totally on secondary data where the World Bank Reports and database regarding doing business have been used to extract the ranks and relevant data of the five countries in respect to the ease of doing business as well as the reforms attempted to support entrepreneurship in these five countries; and the reports and database of 
Enterprise Survey have been used to extract the relevant data regarding the obstacles and challenges that are faced by entrepreneurship activities in these five countries.

The data analysis has been conducted with the help of Microsoft Excel to store arrange and visualize the relevant data to easily distinguish the differences related to the metrics of each country during the last decade and the differences among the five countries in general.

\section{RESULTS AND DISCUSSION}

The findings of the study based on each country's observations are presented below:

\section{(A). Afghanistan:}

\section{Enterprising in Afghanistan:}

The definition of SMEs adopted by the Ministry of Commerce and Industry of Afghanistan is that Micro enterprises employ up to 10 employees with total assets or total annual revenues up to USD 100,000, while small enterprises employ up to 50 employees with total assets or annual revenue up to USD three million, and medium enterprises are the ones who employ up to 300 employees with total assets or annual revenues up to USD 15 million (Siddiqui, 2014).

There are around 400,000 SMEs spread all over the country (Coffey, 2014), and almost 80\% of the Afghan economy consists of small and medium enterprises, accounting for $50 \%$ of the country's GDP and employing more than $30 \%$ of the labor force in the country (Mashal, 2014; Switch-Asia, 2017). Around 70\% - 80\% of small and medium enterprises are in the informal sector and located in rural areas and contribute significantly to the local economy (SwitchAsia, 2017).

\section{The development of the enterprising process in Afghanistan 2009-2019:}

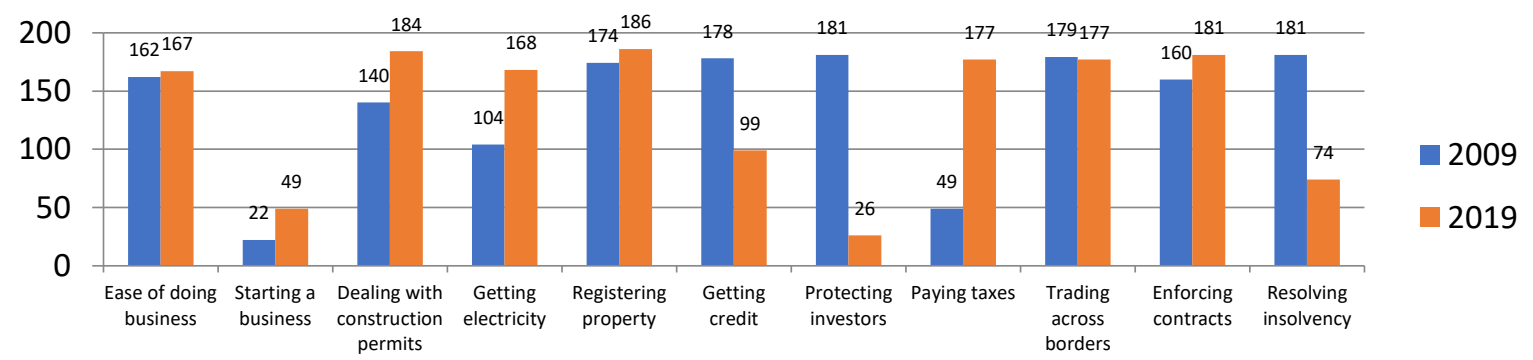

Figure 1 The ranks of doing business factors in Afghanistan during 2009 and 2019.

Source: World Bank, Doing Business database, https://www.doingbusiness.org/en/data

During 2009-2019, Afghanistan did not enhance its rank in respect of the ease of doing business, as it was the $162^{\text {nd }}$ country in 2009 and it dropped down to the $167^{\text {th }}$ position in 2019 among 190 countries worldwide(World Bank, 2008; 2018). A similar decline has been observed in other parameters such as starting a business, dealing with construction permits, electricity, and paying taxes. Further, there have been improvements in terms of accessing credit, solving insolvency, and protecting investors during the last ten years. It is also worth mentioning that the improvements in protecting investors were reported during 2019, and the latest report of the World Bank (Doing Business 2020) shows that protecting investors' interest changed from $26^{\text {th }}$ to $140^{\text {th }}$ which is very alarming. 


\section{Enterprising obstacles and challenges in Afghanistan:}

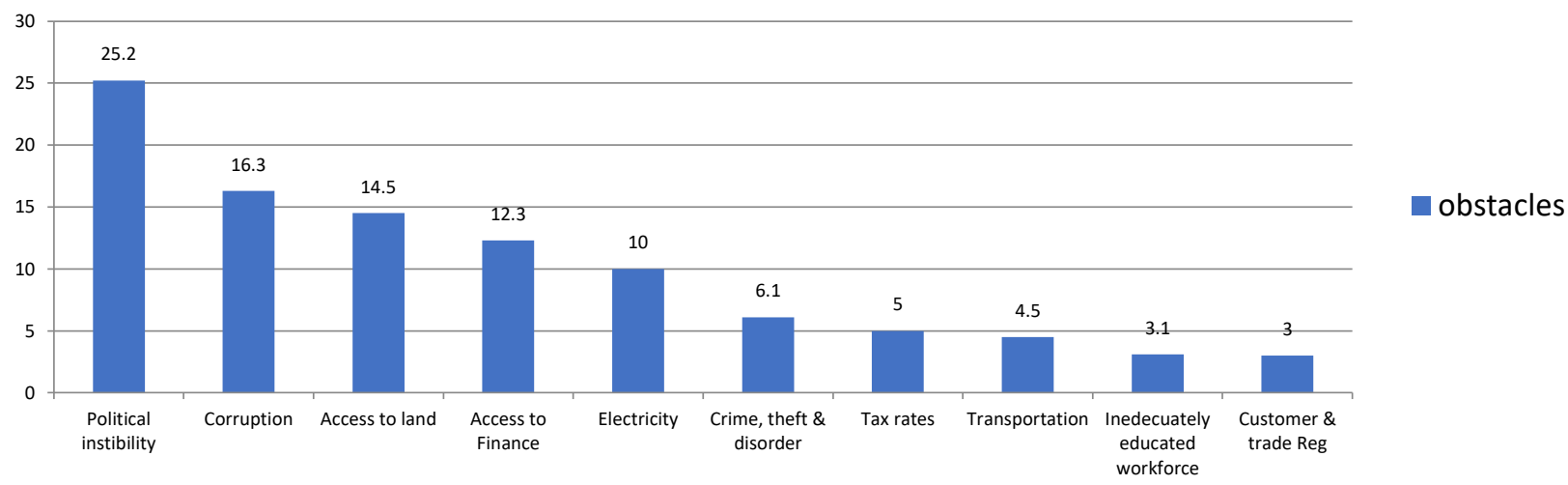

Figure 2: Challenges identified as major obstacles for enterprising - Afghanistan Source: World Bank, Enterprisesurvay database, https://www.enterprisesurveys.org/en/data.

Political instability was reported as the major obstacle by small and medium enterprises in Afghanistan (25.2\%), and around 17\% of SMEs reported that corruption was the major obstacle faced by them in realizing functional objectives; at the same time, access to land, finance and electricity were additional challenges to SMEs in Afghanistan.

\section{Reforms attempted to promote enterprising in Afghanistan:}

There are a good number of reforms adopted to facilitate business initiatives such as; taking company registration out of the commercial courts to simplify business start-up, reducing flat registration fees, reducing property transfer taxes, issuing new regulations broadening the assets that can be used as collaterals (World Bank, 2009), improving the efficiency of the electricity department (World Bank, 2011), reducing the time and cost to obtain a business license, reducing inspection of the premises of newly established enterprises (World Bank, 2013), improving customs processing system (World Bank, 2016), establishing a new credit registry (World Bank, 2014), reducing advanced fees for license, issuing insolvency law to ease accessing credit, adopting a new tax law and administration with better guidelines to improve tax payment procedures (World Bank, 2018). Few reforms were not beneficial for enterprising, such as increasing the registration and publication fees (World Bank, 2014; 2015), requiring three advance years fees for a license (World Bank, 2017).

Table 2: Reforms attempted in favor of enterprising in Afghanistan, Source: World Bank, Doing

Business reports $2009-2019$

\begin{tabular}{|c|c|c|c|c|c|c|c|c|c|c|c|}
\hline Indicators & 2009 & 2010 & 2011 & 2012 & 2013 & 2014 & 2015 & 2016 & 2017 & 2018 & 2019 \\
\hline \multicolumn{12}{|l|}{ Ease of doing business } \\
\hline Starting a business & & $\checkmark$ & & & & $\checkmark$ & $x$ & $x$ & & $x$ & $\checkmark$ \\
\hline \multicolumn{12}{|c|}{ Dealing with construction permits } \\
\hline Getting electricity & & & & $\checkmark$ & & & & & & & \\
\hline Registering property & & $\checkmark$ & & & & & & & & & \\
\hline Getting credit & & $\checkmark$ & & & & $\checkmark$ & & $\checkmark$ & & & $\checkmark$ \\
\hline Protecting investors & & & & & & & & & & & $\checkmark$ \\
\hline Paying taxes & & & & & & & & & $x$ & & $\checkmark$ \\
\hline Trading across borders & & & & & & & & & $\checkmark$ & & \\
\hline \multicolumn{12}{|l|}{ Enforcing contracts } \\
\hline Resolving insolvency & & & & & & & & & & & $\checkmark$ \\
\hline
\end{tabular}

$\bar{V}=$ Reforms that made doing business easier. $\boldsymbol{X}=$ Reforms that made doing business more difficult. 
Regardless of these reforms attempted to encourage enterprising in Afghanistan over the last ten years, they have failed to contribute to the improvement of entrepreneurship/enterprising activities in the country. The business environment in Afghanistan does not seem to attract entrepreneurial activities due to major challenges/hindrances such as political instability, corruption, and access to land.

\section{(B). Bangladesh:}

\section{Enterprising in Bangladesh:}

Small and medium enterprises in Bangladesh are defined by the National Industrial Policy 2016 as follows:

Table 3: Characteristics defining SMEs in Bangladesh. Source: (GOB, 2016).

\begin{tabular}{llll}
\hline Size & Sector & $\begin{array}{c}\text { Maximum } \\
\text { workforce }\end{array}$ & $\begin{array}{c}\text { Fixed Asset (Excluding Building and } \\
\text { land) }\end{array}$ \\
\hline \multirow{3}{*}{ Small } & Service & 25 & USD 6,000 - 60,000 \\
& Business & 25 & USD 6,000 - 60,000 \\
& Industrial & 50 & USD 6,000 - 180,000 \\
& Service & 50 & USD 60,000 - 1,200,000 \\
\multirow{3}{*}{ Medium } & Business & 50 & USD 60,000 - 1,200,000 \\
& Industrial & 150 & USD $180000-2,400,000$ \\
\hline \hline
\end{tabular}

Source: Authors

In Bangladesh, 99\% of establishments in the private sector are small and medium enterprises, accounting almost to providing almost $80 \%$ of industrial development (Ahmed, 2015). This upholds the role and contribution of small and medium enterprises in creating jobs and income generation, poverty alleviation and entrepreneurship development in the economy. Bangladesh with 6,000,000 enterprises they contribute one quarter of the country's GDP, and other sectors like agriculture accounts for $15.1 \%$, industry accounts for $28.6 \%$ and the service sector accounts for $56.3 \%$ (Switch-Asia, 2017a).

\section{The development of the enterprising process in Bangladesh 2009-2019:}

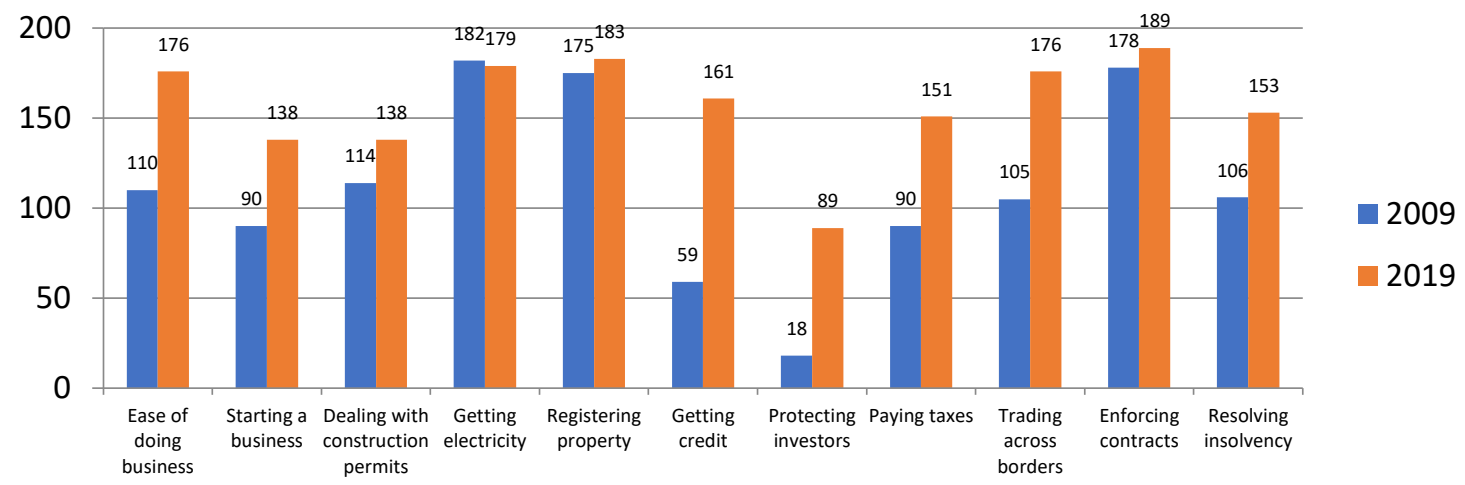

Figure 3: The ranks of doing business factors in Bangladesh during 2009 and 2019.

Source: World Bank, Doing Business database, https://www.doingbusiness.org/en/data

Doing business in Bangladesh was not made any easier for entrepreneurs during the short period, as Bangladesh was ranked as $110^{\text {th }}$ country in terms of ease of doing business during 2009 and was ranked $176^{\text {th }}$ country in 2019 (World Bank, 2008; 2018). Starting business was felt very difficult as entrepreneurs had to go through nine procedures in 2019 instead of seven procedures in 2009, even though the time to process the same was reduced from 73 days in 
2009 to 19.5 days in 2019, yet, Bangladesh is ranked 138 in 2019 against its $90^{\text {th }}$ position in 2009. Protecting investors is another area that is in need of reform in Bangladesh as against the $18^{\text {th }}$ and in 2009 is placed at $89^{\text {th }}$ in 2019 . Other factors such as access to electricity, credit, registering properties, and enforcing contracts have not witnessed any improvements to ease entrepreneurship activities in the country. This implies the need for critical reforms for accelerating entrepreneurial activities in the country.

\section{Enterprising obstacles and challenges faced by Bangladeshi enterprises:}

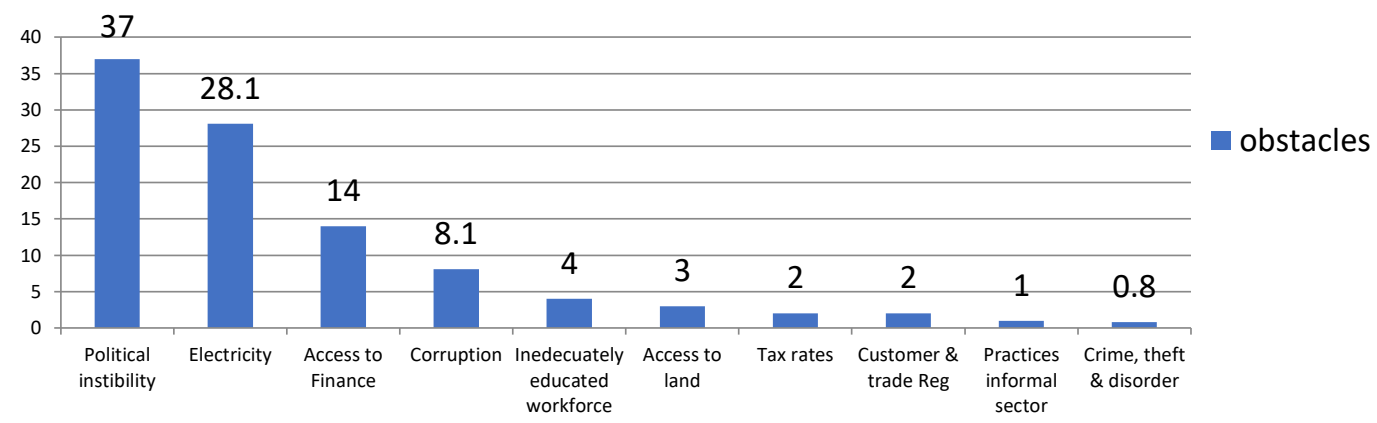

Figure 4: Challenges identified as major obstacles for enterprising - Bangladesh.

Source: World Bank, Enterprisesurvay database, https://www.enterprisesurveys.org/en/data.

Similar to Afghanistan, more than $35 \%$ of small and medium enterprises in Bangladesh reported that political instability as the major obstacle to their functional activities. Access to electricity and credit are the other two major obstacles for undertaking entrepreneurship. Fewer enterprises in Bangladesh also reported corruption as one of the major obstacles unlike in Afghanistan.

\section{Reforms attempted to promote enterprising in Bangladesh:}

Bangladesh has undertaken various measures to reform and ease the process of doing business during the last ten years; such as reducing time and cost of registering enterprises (World Bank, 2008; 2013), setting up of full-fledged online process for business name clearance, reducing corporate income tax rates, automating customs clearance procedures (World Bank, 2009; 2014), reducing property transfer tax (World Bank, 2010), the establishment of an online platform for sharing information relating to credit access/sources (World Bank, 2012). Reforms in light of major hindrances faced; such as shortage of electricity supply made it difficult to conduct business activities (World Bank, 2011; 2012), against this the application processing time to obtain a new electricity connection was improved (World Bank, 2015). The time to prepare and submit VAT and corporate income tax returns was increased (World Bank, 2016). An increase in the cost of business registration at the Registrar of Joint Stock Companies and Firms (World Bank, 2017), is still a hindering factor for enterprising. The summary of the above has been presented in the table below.

Table 4: Reforms attempted in favor of enterprising in Bangladesh. Source: World Bank, Doing Business reports $2009-2019$.

\begin{tabular}{lccccccccccc}
\hline \hline Indicators & 2009 & 2010 & 2011 & 2012 & 2013 & 2014 & 2015 & 2016 & 2017 & 2018 & 2019 \\
\hline \hline Ease of doing business & & & & & & & & & & & \\
Starting a business & $\checkmark$ & $\checkmark$ & $\checkmark$ & & & $\checkmark$ & & & & \\
Dealing with construction permits & & & & & & & & & & \\
Getting electricity & & & & $\mathrm{X}$ & $\mathrm{X}$ & & & & & & \\
\hline \hline
\end{tabular}




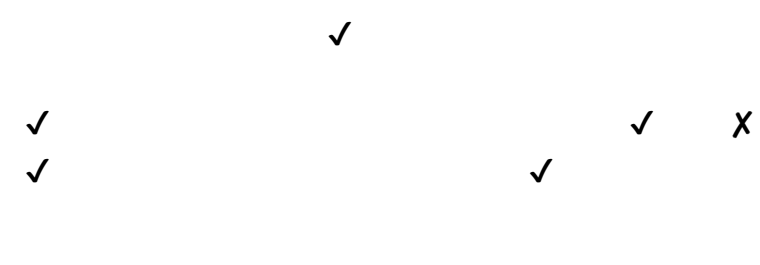

Enforcing contracts

Resolving insolvency

$\checkmark=$ Reforms that made doing business easier. $\boldsymbol{X}=$ Reforms that made doing business more difficult. Source: Authors

A comprehensive insight into the analysis unveils that, as like Afghanistan, political instability, access to electricity and access to finance are majorly affecting the enterprising process as reported by enterprises. Further, reforms initiated have not remarkably impacted on improving enterprising in the country. This implies the absence of an encouraging and conducive business environment is reflected in the lack of development in enterprising activities in Bangladesh.

\section{(C). Rwanda:}

\section{Enterprising Background in Rwanda:}

The Government of Rwanda defines small and medium enterprises based on three conditions where two of them must be met to fit in the category. These conditions are the net capital investments, annual turnover, and the number of employees (Minicom, 2010a).

Table 5: Definitions and characteristics of MSMEs in Rwanda. Source: (Minicom, 2010a).

\begin{tabular}{llll}
\hline \hline Size of the Enterprise & Net capital investments & Annual Turn over & Number of Employees \\
\hline \hline Micro Enterprises & Less than USD 550 & Less than USD 320 & 1 to 3 \\
Small Enterprises & USD 550 - 16,000 & USD 320 - 13, 000 & 4 to 30 \\
Medium Enterprises & USD 16,000 - 80,000 & USD 13,000 - 54,000 & 31 to 100 \\
Large Enterprises & More than USD 80,000 & More than USD 54,000 & More than 100 \\
\hline \hline
\end{tabular}

Source: Authors

Due to the small size of the country and its population, small and medium enterprises dominate the private sector accounting for $97.8 \%$ employing $41 \%$ of the population. There are around 137,699 small enterprises in the informal sector in Rwanda, while there are only 10,018 enterprises in the formal sector which includes; public, cooperative, private, and mixed businesses (National Institute of Statistics of Rwanda, 2015), and this sector has around 300,000 employees (Minicom, 2010; 2010a). The Rwandan industrial sector is still young yet fast-growing. While the manufacturing sector contributes $14.8 \%$ of the country's GDP, the service sector contributes $43.6 \%$ to the country's GDP while is growing faster than the industrial sector (Nsengimana, 2017).

The development of the enterprising process in Rwanda 2009-2019: 


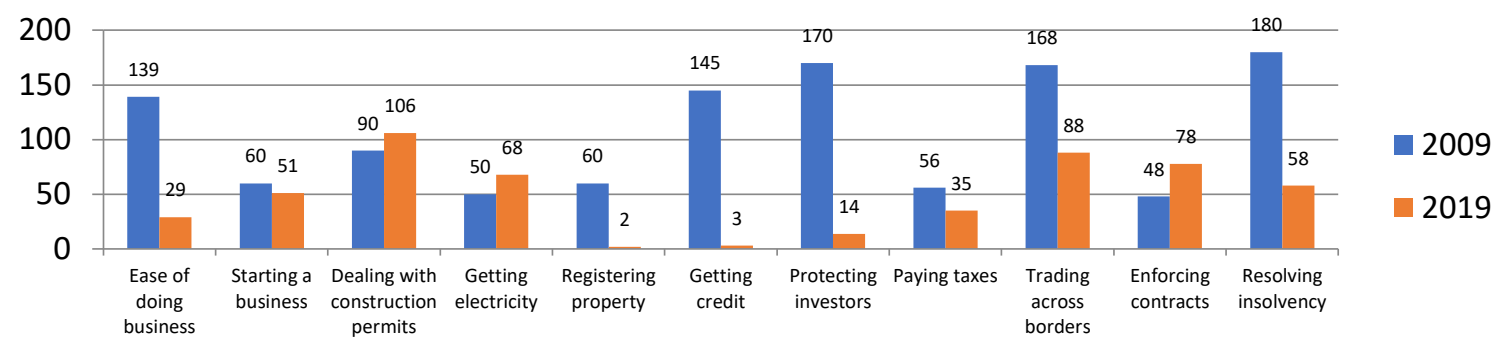

Figure 5: The ranks of doing business factors in Rwanda during 2009 and 2019.

Source: World Bank, Doing Business database, https://www.doingbusiness.org/en/data

When compared to other least developed countries (in this study), Rwanda has achieved significant development; in respect, of the factors of doing business regardless of the economic crisis that followed the genocide in 1994. Rwanda which was ranked as $139^{\text {th }}$ country in ease of doing business during 2009 has been ranked $29^{\text {th }}$ country during 2019. Starting a business in Rwanda in 2019 entrepreneurs to go through eight procedures, wait fourteen days and pay fees around $108.9 \%$ of per capita income; which saw major reforms during 2019 where starting a business requires entrepreneurs to go through five procedures, waiting period reduced to four days and fees were also reduced to $14.8 \%$ of per capita income (World Bank, 2008, 2018). A significant development was also witnessed with regards to registering property, access to credit, investors protection, cross-border trading, and providing resurgence to insolvent entrepreneurs.

\section{Enterprising obstacles and challenges in Rwanda:}

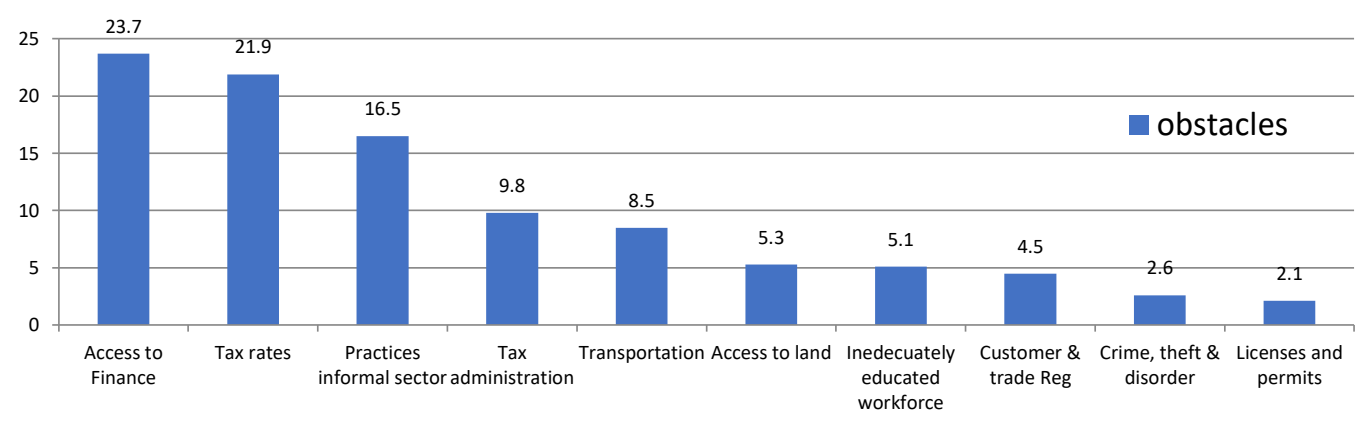

Figure 6: Challenges identified as major obstacles for enterprising - Rwanda.

Source: World Bank, Enterprisesurvay database, https://www.enterprisesurveys.org/en/data.

In Rwanda, the major obstacle reported by $24 \%$ of SMEs is the ease of access to finance which is also a common obstacle for small and medium enterprises worldwide. $22 \%$ of SMEs reported prevailing tax rates as an obstacle to their entrepreneurial activities. Contemporary practices of the informal sector were reported as the third major obstacle to entrepreneurship by $16 \%$ of SMEs in Rwanda. This upholds the need/importance of realizing a stable economic and political system to create a sound enterprising environment in the economy.

\section{Reforms attempted to promote enterprising in Rwanda:}

Rwanda has been a great example in conducting reforms among the five least developed countries considered in this study during the years 2009-2019, which encouraged enterprising. Constructive reforms to support enterprising attempted in Rwanda include introducing one application to obtain construction permits (World Bank, 2008; 2010), with reduced fees (World Bank, 2014), risk-based inspections (World Bank, 2017), establishing commercial courts 
(World Bank, 2008), reducing time and cost for enterprise and property registration (World Bank, 2008;2009; 2011; 2013), through the electronic system (World Bank, 2013), and easing the process (World Bank, 2016).

Reforms related to accessing resources include: allowing a wide range of assets to be used as collaterals, establishing a new company law and another law to streamline reorganization procedures, eliminating the notarization requirement to start a business (World Bank, 2009), reporting credit reports to central bank's public credit registry, issuing building regulations to ease construction permits (World Bank, 2010), publishing data to improve the credit information system (World Bank, 2011) for which the banks were given credit scores against expanded borrower coverage (World Bank, 2015), the frequency of filing value-added tax was reduced from monthly to quarterly (World Bank, 2011), and filing returns electronically was made compulsory (World Bank, 2015), in other words, filing returns was carried out through online services (World Bank, 2017).

Property transfer was very expensive, and this hampered property registration (World Bank, 2011), and was carried out through online services (World Bank, 2017). Fees for new electricity connections were reduced (World Bank, 2012; 2014; 2018), an electronic system for filing complaints was implemented (World Bank, 2012). New regulations for protecting investors' interest (World Bank, 2013), and allowing minority investors to call for an extraordinary meeting of shareholders were promoted (World Bank, 2015). Further, it was also made easier to sue directors against failure of compliance (World Bank, 2017). The property tax rate was reduced, and an electronic filing system was introduced, this acted as a single-window system at the border and a new law for insolvency proceedings was initiated (World Bank, 2013).

Enterprises that were required to buy a certified electronic billing machine (World Bank, 2014) were later replaced by free software for value-added tax invoices (World Bank, 2018). Possessing a bank account was not mandatory to register for VAT, new urban planning regulations and building code was issued (World Bank, 2015). Preshipment inspection, which was mandatory for imported products hampered trade across borders (World Bank, 2015), which was later removed (World Bank, 2016). Obtaining a building became mandatory for obtaining permits, and payment of social security contributions was made monthly instead of quarterly (World Bank, 2016). Enforcing contracts was improved; by providing, judges and lawyers with online case management systems (World Bank, 2016), introducing new rules of civil procedures (World Bank, 2018), increasing the transparency of the land administration system (World Bank, 2016), increasing working hours of custom points (World Bank, 2008), and implementing a single customs territory (World Bank, 2018). A new insolvency law was issued, to improve the land dispute resolution mechanisms under the land administration system (World Bank, 2018).

However, the latest report of the World Bank "Doing Business 2020" states that Rwanda has adopted new reform measures, such as exempting newly formed enterprises from payment of trading license tax for their first two years, has reduced the turnaround time for getting water and sewage connection, making insurance on building as a requirement of once used by enterprises, and upgraded the power grid infrastructure to supply electricity. 
Table 6: Reforms attempted in favor of enterprising in Rwanda. Source: World Bank, Doing Business reports $2009-2019$.

\begin{tabular}{lccccccccccc}
\hline Indicators & 2009 & 2010 & 2011 & 2012 & 2013 & 2014 & 2015 & 2016 & 2017 & 2018 & 2019 \\
\hline Ease of doing business & & & & & & & & & & & \\
Starting a business & & $\checkmark$ & & $\checkmark$ & & $\checkmark$ & $X$ & $\checkmark$ & $\checkmark$ & & $\checkmark$ \\
Dealing with construction permits & $\checkmark$ & & $\checkmark$ & & & $\checkmark$ & $\checkmark$ & $\checkmark$ & $X$ & $\checkmark$ & \\
Getting electricity & & & & & $\checkmark$ & & $\checkmark$ & & & & $\checkmark$ \\
Registering property & $\checkmark$ & $\checkmark$ & & $\times$ & & $\checkmark$ & & & $\checkmark$ & $\checkmark$ & $\checkmark$ \\
Getting credit & & $\checkmark$ & $\checkmark$ & $\checkmark$ & & $\checkmark$ & $\checkmark$ & $\checkmark$ & & & $\checkmark$ \\
Protecting investors & & $\checkmark$ & & & & $\checkmark$ & & $\checkmark$ & & $\checkmark$ & \\
Paying taxes & & $\checkmark$ & & $\checkmark$ & & $\checkmark$ & & $\checkmark$ & $\checkmark$ & $\checkmark$ & \\
Trading across borders & $\checkmark$ & $\checkmark$ & $\checkmark$ & & & $\checkmark$ & & $\checkmark$ & $\checkmark$ & & $\checkmark$ \\
Enforcing contracts & $\checkmark$ & & & & $\checkmark$ & & & & $\checkmark$ & $\checkmark$ & $\checkmark$ \\
Resolving insolvency & & $\checkmark$ & & & & $\checkmark$ & & $\checkmark$ & & & $\checkmark$ \\
\hline \hline
\end{tabular}

$\checkmark=$ Reforms that made doing business easier. $\boldsymbol{X}=$ Reforms that made doing business more difficult.

Source: Authors

Lookin at all the above, it becomes very obvious that Rwanda has significantly achieved inclusive development in respect of doing business factors, by creating an efficient business environment and infrastructure to encourage entrepreneurship and enterprising activities. Therefore, the challenges reported are not related to infrastructure and stability, unlike Afghanistan and Bangladesh. Reforms and adopted policies have effectively participated/intervened in accomplishing the objective of the development of a sound Rwandan business environment.

\section{(D). Sudan:}

\section{Enterprising Background in Sudan:}

There is no clear definition of small and medium enterprises available in the literature adopted by the Government of Sudan. However, small and medium enterprises in Sudan are defined as enterprises that employ up to 50 full-time employees, with an investment capital of less than USD 86,000 (Saqr, 2019). There is no substantial evidence available in the literature (statistics) about the participation of small and medium enterprises sectorally in the Sudanese economy, even though the literature citing the fact that this sector is playing a crucial part in the economic growth of Sudan (Eltahir, 2018).

\section{The development of the enterprising process in Sudan 2009-2019:}

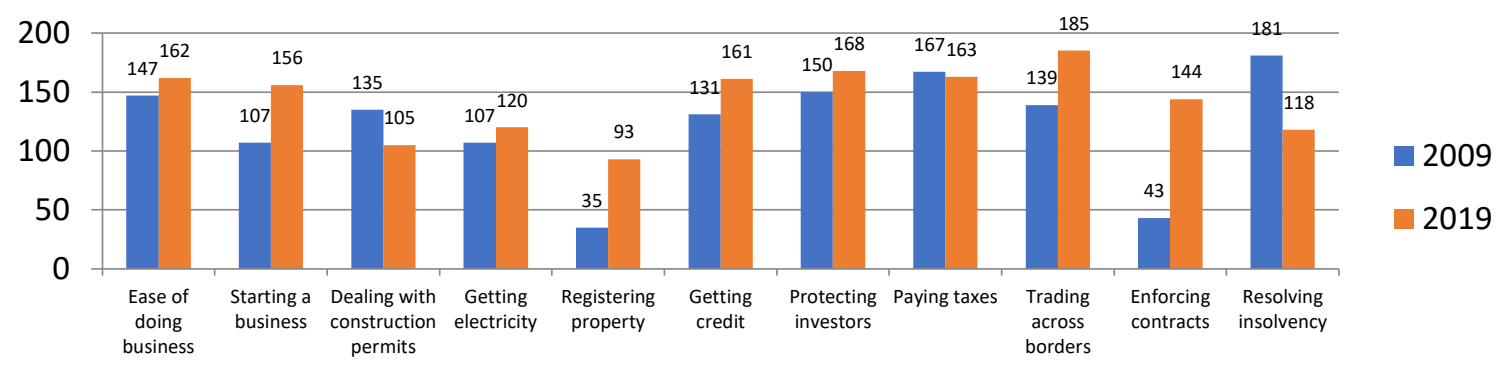

Figure 7: The ranks of doing business factors in Sudan during 2009 and 2019.

Source: World Bank, Doing Business database, https://www.doingbusiness.org/en/data

There was no significant development witnessed in doing business in Sudan as the rank of Sudan has seen a decline from 147 during 2009 to 162 in 2019. Important factors to do business 
such as accessing credit, registering property, protecting investors and enforcing contracts had worsened in Sudan over the last ten-year period. Dealing with construction permits and resolving insolvency had witnessed a slight development in their contribution towards the growth of entrepreneurship. However, it is less when compared to other factors that did not witness any improvement in the economy.

\section{Enterprising obstacles and challenges in Sudan:}

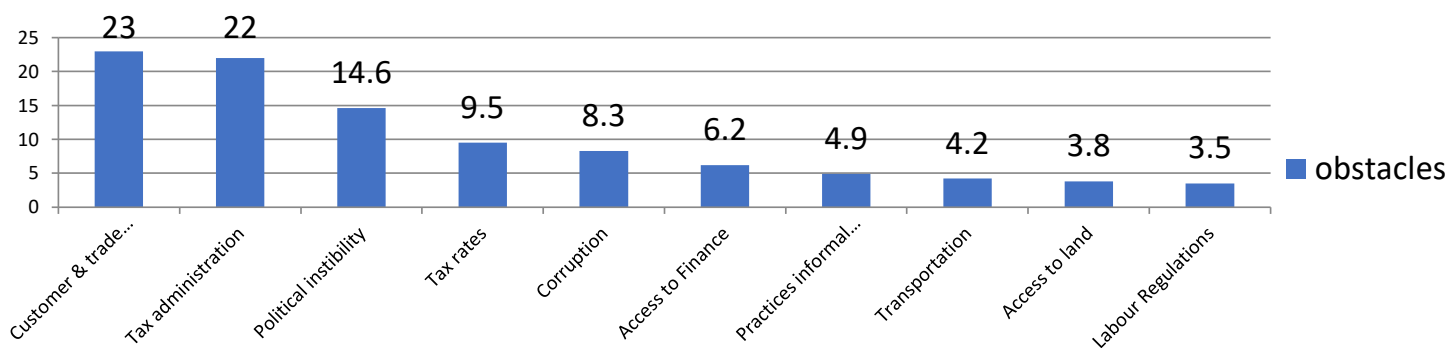

Figure 8: Challenges identified as major obstacles for enterprising - Sudan.

Source: World Bank, Enterprisesurvay database, https://www.enterprisesurveys.org/en/data.

As shown above, $23 \%$ of SMEs in Sudan claim customer and trade regulation as the major obstacle hampering entrepreneurship activities. $22 \%$ and $14 \%$ of SMEs respectively claim administering taxes and political instability are the second and third most critical challenges that entrepreneurship activities are exposed to in Sudan; which implies the critical need for regulatory and administrative reforms to prepare a conducive environment to promote entrepreneurial activities in the economy.

\section{Reforms attempted in favor of enterprising in Sudan:}

Sudan has made more/better attempts than Yemen during the last ten years, some of the very important ones are reducing corporate and income tax, abolishing the labor tax, facilitating customs declaration procedures (World Bank, 2009), establishing a private credit bureau to ease access to credit (World Bank, 2012), amending Companies Act to facilitate access to credit (World Bank, 2018). The reform initiative which hindered the activities was the increase in the cost for a company seal, which made it difficult to sue directors (World Bank, 2016), weakening the protection of minority investors. Site inspection requirement was removed easing access to evidence in shareholder litigation to increase investors' protection, recognizing mediation as well as voluntary conciliation to end commercial disputes which enhanced enforcing contracts and allowing the business of the debtor during insolvency proceedings (World Bank, 2018).

Table 7: Reforms attempted in favor of enterprising in Sudan. Source: World Bank, Doing Business reports $2009-2019$.

\begin{tabular}{|c|c|c|c|c|c|c|c|c|c|c|c|}
\hline Indicators & 2009 & 2010 & 2011 & 2012 & 2013 & 2014 & 2015 & 2016 & 2017 & 2018 & 2019 \\
\hline \multicolumn{12}{|c|}{ Ease of doing business } \\
\hline Starting a business & & & & & & & & & $x$ & & $\checkmark$ \\
\hline \multicolumn{12}{|c|}{ Dealing with construction permits } \\
\hline \multicolumn{12}{|c|}{ Getting electricity } \\
\hline \multicolumn{12}{|l|}{ Registering property } \\
\hline Getting credit & & & & & & & & & & & $\checkmark$ \\
\hline Protecting investors & & & & & & & & & $x$ & & $\checkmark$ \\
\hline Paying taxes & & $\checkmark$ & & & & & & & & & \\
\hline
\end{tabular}




\begin{tabular}{lcc}
\hline \hline Trading across borders & $\checkmark$ & \\
Enforcing contracts & & $\checkmark$ \\
Resolving insolvency & $\checkmark$ \\
\hline \hline$\checkmark=$ Reforms that made doing business easier. $X$ = Reforms that made doing business more difficult
\end{tabular}

$\checkmark=$ Reforms that made doing business easier. $\boldsymbol{X}=$ Reforms that made doing business more difficult Source: Authors

From the above, it can be observed that the literature lacks detailed information about the precise size and contribution of small and medium enterprises in Sudan. However, the World Bank's reports unveil that during the last ten years, Sudan has not witnessed any significant development in the enterprising process and entrepreneurial activities. Administrative reforms became very essential to the tax administration, customer and trade regulations were reported to be the major challenges for enterprising in Sudan.

\section{Yemen:}

\section{Enterprising Background in Yemen:}

Yemen though lacks a universal definition for MSMEs (Alnedhari, 2009; Alsabai, 2011). Central Statistical organization defines large enterprises as the ones with more than 10 employees, medium enterprises are the ones with 4-9 employees, and small enterprises are the ones who employ 1-4 employees (CSO, 2005). While the baseline survey conducted during 2000, categorized enterprises as micro with one employee (self-employed), small enterprises employing 2-4 employees, and medium enterprises with 5-50 employees (Aliriani, 2013).

The only official definition available is the one mentioned in the "National Strategy for Micro and Small Enterprises Development" which was issued in 2005, it categorizes enterprises; the micro-enterprises having 1-4 employees, small enterprises having 5-50 employees, and enterprises having more than 50 employees are considered as large enterprises (PSDP, 2011; Alnedhari, 2009; Aliriani, 2013). The economy of Yemen is considered to be the poorest in the MENA region. It is the economy reeling from poverty, unemployment, illiteracy, and a fragmented geographically skewed infrastructure. Micro, small and medium enterprises in Yemen account for 97\% of the business sectors, with 290,000 enterprises with less than 25 workers and employing around 600,000 workers in them (Assaf, 2013). Small and smaller enterprises employ around $44.5 \%$ of the workforce, while medium enterprises employ $19.5 \%$ and $36 \%$ are employed by large enterprises (CSO, 2017).

\section{The development of the enterprising process in Yemen 2009-2019:}

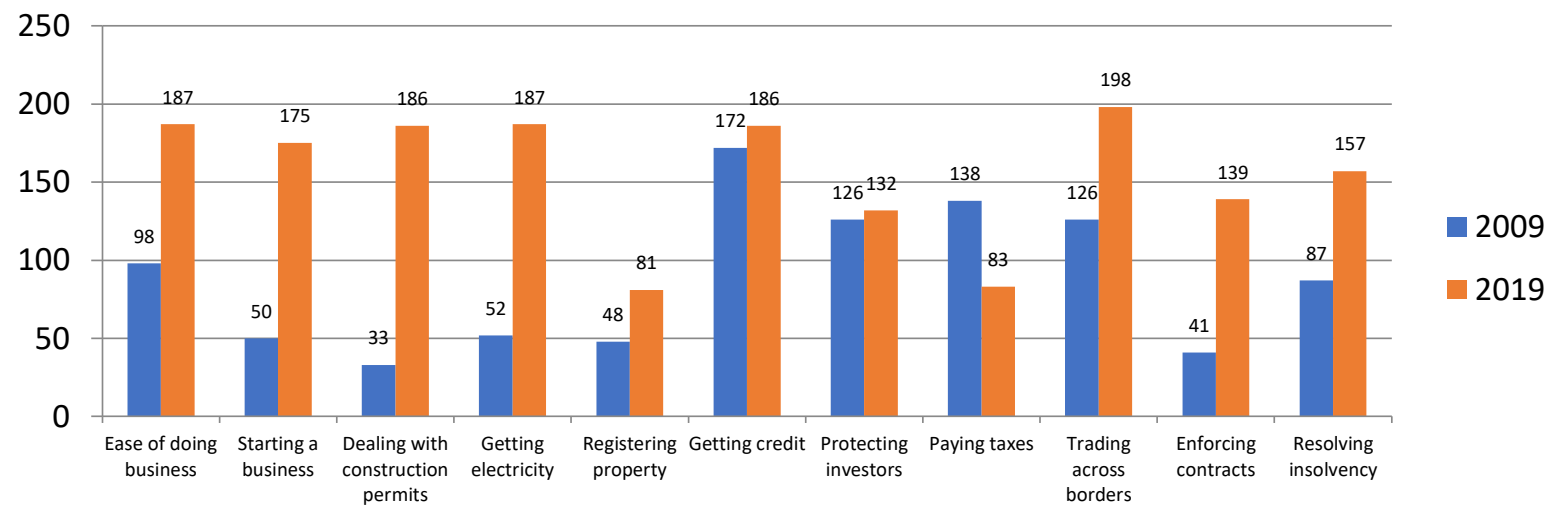

Figure 9: The ranks of doing business factors in Yemen during 2009 and 2019.

Source: World Bank, Doing Business database, https://www.doingbusiness.org/en/data 
For the last few years, Yemen has been located in the tail of countries in respect of doing business factors. Yemen was ranked as the $98^{\text {th }}$ country in term of ease of doing business in 2009 and dropped down to $187^{\text {th }}$ country in the list among 190 countries during 2019 (World Bank, 2008; 2018). Currently, an entrepreneur is required to wait 40 days to process starting a business as against 14 days back in 2009. The fee payable was around $93 \%$ of per capita income in 2009, which during 2019rose to $118.8 \%$ of per capita income (World Bank, 2008; 2018). Furthering to this, the current conflict and political unrest has a big effect on the business process and development efforts and is acting as a severe deterrent factor. The status of lawlessness in the country has worsened the development efforts for undertaking business processes. Dealing with construction permits, getting electricity, accessing credit, registering property, protecting investors, and enforcing contracts have all worsened during the last ten years [as shown in figure 9].

\section{Enterprising obstacles and challenges in Yemen:}

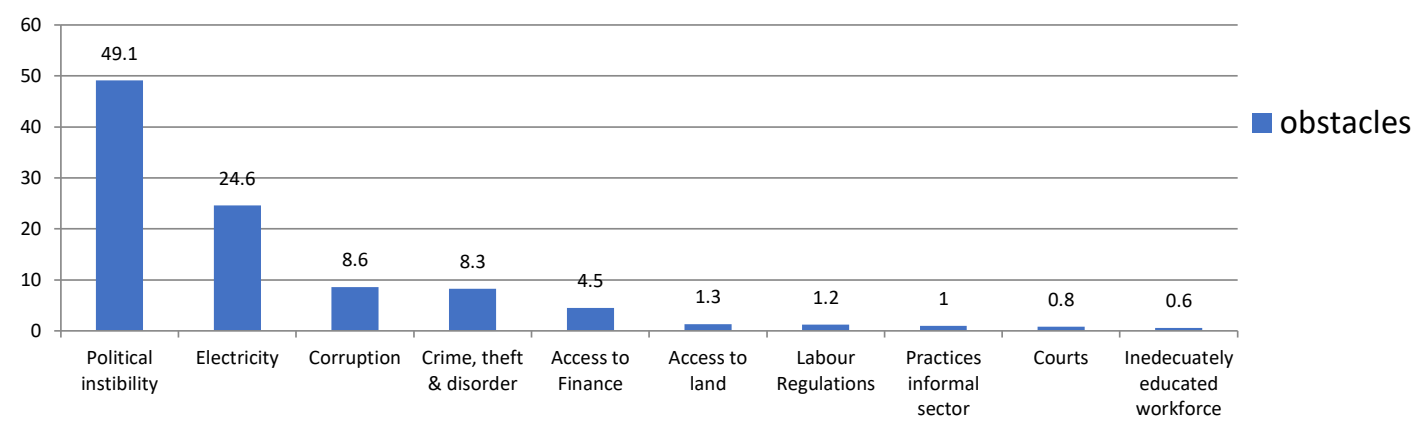

Figure 10: Challenges identified as major obstacles for enterprising - Yemen.

Source: World Bank, Enterprisesurvay database, https://www.enterprisesurveys.org/en/data

In Yemen, political instability has been the major hindrance for enterprising and entrepreneurship activities (as identified by half of SMEs in the country); 24\% of SMEs identified electricity as a major obstacle to enterprising. While only a small portion of SMEs have identified access to finance and land, corruption, crime and theft, labor regulations as the major obstacles for their business. This unveils the severity of the effects of political instability, the lack of development and infrastructure for undertaking business in Yemen.

\section{Reforms attempted in favor of enterprising in Yemen:}

When it comes to reforming efforts, Yemen has reduced the time and number of procedures to start a business by eliminating the requirements of company seal and paid-in minimum capital (World Bank, 2008), eliminated the need for providing the bank account certificate for registration, implemented an electronic data interchange system and a risk-based inspection system to facilitate cross border trading (World Bank, 2009), general corporate tax rates have been reduced from $35 \%$ to $20 \%$ (World Bank, 2011). Some of the reforms that have negatively impacted the development of enterprising activities include, eliminating the one-stop-shop service for registration (World Bank, 2011), and reducing operation at ports during 2015 in response to the violent conflict affecting trading across borders (World Bank, 2015).

Table 8: Reforms attempted in favor of enterprising in Yemen. Source: World Bank, Doing Business reports $2009-2019$.

\begin{tabular}{llllllllllll}
\hline \hline Indicators & 2009 & 2010 & 2011 & 2012 & 2013 & 2014 & 2015 & 2016 & 2017 & 2018 & 2019 \\
\hline \hline
\end{tabular}


Ease of doing business

Starting a business

Dealing with construction permits

Getting electricity

Registering property

Getting credit

Protecting investors

Paying taxes

Trading across borders

Enforcing contracts

Resolving insolvency

$\checkmark=$ Reforms that made doing business easier. $\boldsymbol{X}=$ Reforms that made doing business more difficult

Source: Authors

From the above observations, we can conclude that Yemen is the country attempting the least reform measures, regardless of the decline of its rank among other countries in terms of "doing business" factors. The SMEs sector in Yemen is exposed to a tremendous amount of challenges and obstacles (Saleh \& Manjunath, 2020), coupled with the impact caused by the recent instability that the country is witnessing currently (Saleh\& Manjunath, 2020a). The active conflict which is going on in Yemen has a significant influence on the enterprising activities and the development of entrepreneurship in the economy. This exerts lots of pressure on policymakers and international organizations to cooperate and create a conducive environment for small and medium enterprises to function and grow in the economy. However, there is a lack of intent in attempting reforms in the enterprising activities among SMEs in Yemen, which is very essential to bring in economic and industrial resurgence.

This maximized the need for extra efforts to be dedicated towards the development of entrepreneurship activities which can lead to an entrepreneurial change in the economy. The literature presents evidence that paying essential attention towards developing the essential skills among the youth and developing skilled human capital can participate effectively towards cultivating entrepreneurial activities in the Yemeni community (Saleh et al., 2021). It is also observed that the efforts made in respect to education and training among the youth in Yemen can contribute towards developing their attitudes and their perception level towards entrepreneurship (Saleh \& Manjunath, 2020b; 2021a), this results in achieving entrepreneurial progress stemming from such efforts made for educating the youth.

\section{Discussion:}

Among the five least developed countries, Rwanda is the only economy that has achieved significant developments relating to establishing a new business and the process of doing business. This is achieved by adopting policies and attempting reforms, which is very much evidential as Rwanda which was ranked the $139^{\text {th }}$ country in the ease of doing business in 2009 (World Bank, 2008) emerged as the $29^{\text {th }}$ country in 2019 (World Bank, 2018). Further, the entrepreneurs who were required to go through eight procedures, and wait for fourteen days, pay a fee equal to $108.9 \%$ of the per capita income during 2009 (World Bank, 2008) are now required to go through five procedures, wait for four days and pay a fee around $14.8 \%$ of per capita income (World Bank, 2018). These aspects are creating a positive spur among youth to undertake entrepreneurship against seeking employment either with the government or nongovernment organizations/institutions. 
A detailed classification and definition of small and medium enterprises are adopted in Rwanda, regardless of the (small) size of the country and its population. However, due to encouraging competitive business environment in the country, (unlike other least developed countries) by the Rwandan Government in respect of almost every factor of doing business, it has ensured the innovative performance of small and medium enterprises are inclined in the objective of inclusive growth. This has Rwanda as an example of a leading developing country that other least developed countries should embrace and similar development strategies need to be followed by them to achieve inclusive development. Post the genocide, the government of Rwanda mobilized possible resources to rebuild education after the destruction that was caused to the education sector. In addition to its education policies, measures to reform education and focus on building practical skills were initiated by introducing student-centered and interactive pedagogy (Obura, 2003; Blimpo and Pugatch, 2019). These education reforms have played a key role in peacebuilding particularly through transforming the values of learners and providing cognitive rewards (Taka, 2020). This has enabled humanization and has led towards achieving remarkable development in a short time which is also reflected in the high score of Rwanda in Human Development Index, which was 0.25 in 1990 and during 2019 has increased to 0.524 (Afolayan, 2015).

Rwanda survived the genocide of 1994 (which ended with the death of almost a million people). Through rebuilding efforts to re-orient the country from the conflict that was rooted in the history of Rwanda towards a system, that privileges national reconciliation and unity (GoloobaMutebi, 2008; Kumar, et. al. 1996). The President of Rwanda stated that after the genocide, when people were all broken and everything was a priority, Rwanda resurged into an emerging economy today by adopting three potential choices which were staying together, being accountable and the choice to think big (Kagame, 2014). The significant growth and development achieved in Rwanda during 2009-2019 (Georgieva, 2018) can be attributed to the policies adopted coupled with reform efforts aiming to reduce poverty and provide better public service through cooperation with international development partners, NGOs, the private sector, and central governments. This has helped to fight social and economic underdevelopment and focus on investments, infrastructure, and education.

Major policies adopted in Rwanda Vision 2020, Poverty Reduction Strategy Paper, Economic Development and Poverty Reduction Strategy: 2008-2012, and Economic Development and Poverty Reduction Strategy II: 2013-2018, were of laissez-faire and neo-liberalism prioritizing the promotion of the private sector through the development of a sound business environment. They aimed at building an economy that is knowledge-based and private sector-led, along with poverty reduction, transforming Rwanda into a middle-income country by end of 2020 . This requires focusing on five priorities which are; increasing the domestic interconnectivity of the economy, boosting exports, transitioning and developing the private sector through investments, increasing urban development, and transforming through pursuing a green economy (Government of Rwanda, 2000; 2002; 2007; 2013). These factors have provided for significant economic performance and development in Rwanda and would continue to be driven by good governance in the country. Sustaining development in the country also requires strong politico-socio-economic policies (Habyarimana and Dushimayezu, 2018). Adopting such experience to other least developed countries is supposed to be contributive with respect to economic growth and entrepreneurial change (Ngabonziza, 2015). 
The study based on these experiences/observations suggests the following fundamental model of the key drivers of entrepreneurial change, which also triggers the need for future investigations and research. Adopting this model in the least developed countries would act as a roadmap that drives the economy towards achieving entrepreneurial change (as in the case of Rwanda)- and transform from a deteriorated country reeling from poverty and ethnic dispute to a fast-developing economy.

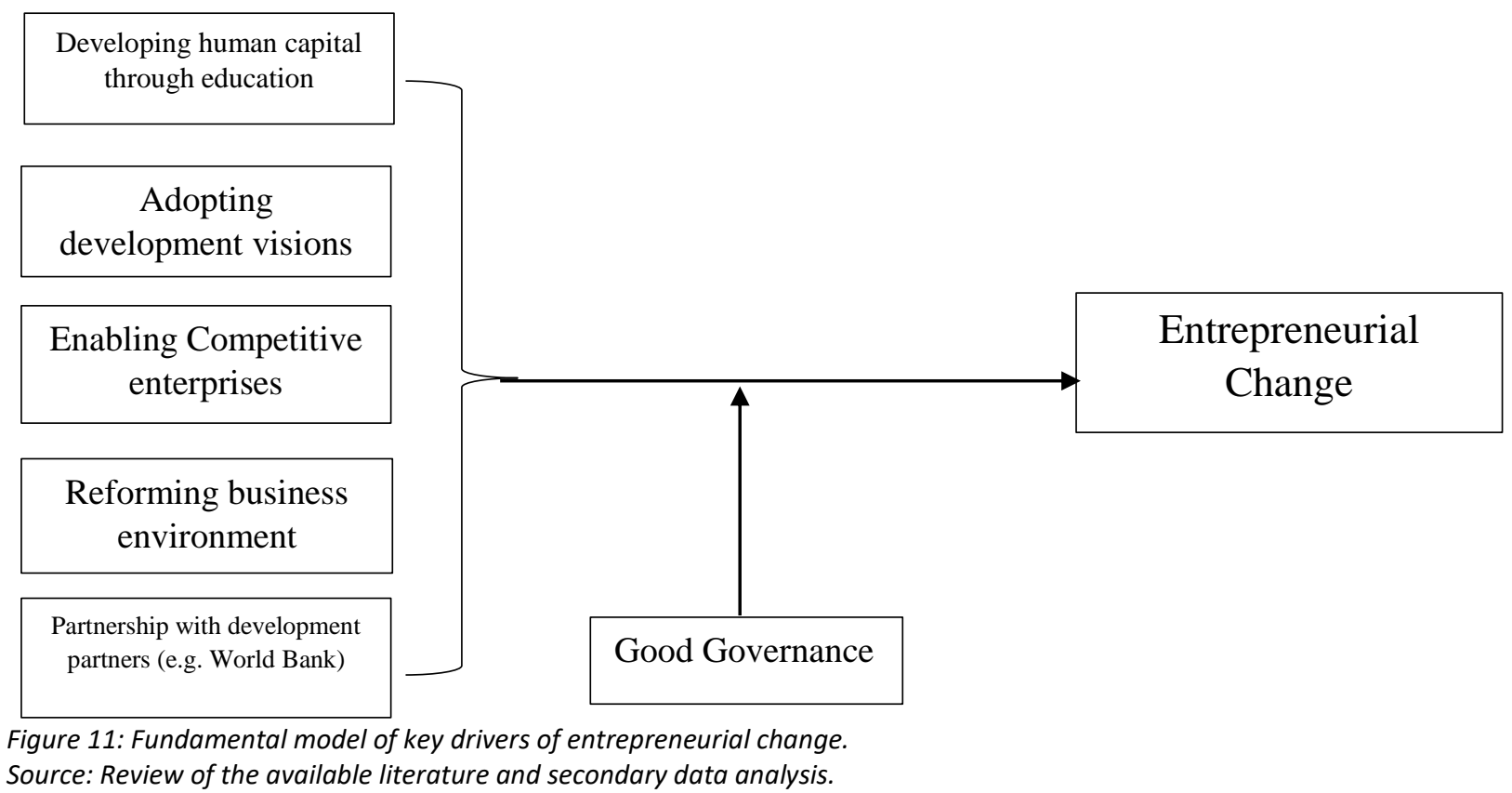

To support enterprising activities and create a positive spur in youth for undertaking entrepreneurship, Yemen is in need to embrace the Rwandan experience - which would help the economy to survive the economic and political instability which hampers the development efforts and activities in the economy. Due to the similarity between the current condition of Yemen and the Rwandan condition after the genocide, Yemen has a lot to learn from Rwanda; be it the policies, reform efforts, or the cooperation and commitment towards international development partners. This also raises questions about its contextual relevance to Yemen and triggers the need for the attention of the policymakers towards the appropriate agenda that can gear up the economy towards developing enterprising in the country and creation of a competitive business environment to move towards entrepreneurial change.

\section{CONCLUSION AND SUGGESTION}

It can be concluded that embracing the Rwandan experience in developing strategies and structural reforms can and should be beneficial to achieve growth, provide economic welfare and entrepreneurial change in Yemen. Rwanda experienced political and economic instability before and after the Rwandan genocide, therefore, paying attention to support and supervising enterprising activities and entrepreneurial development became very crucial and was significantly effective in achieving a remarkable development in respect of establishing SMEs, doing business, and contributing to the growth of entrepreneurship. Further, the study concludes that Yemen, along with the other three other LDCs, is in need of adopting the dimensions of the entrepreneurial change which involve developing the human capital of the country, adopting development visions and strategies, enabling competitive strategies, 
reforming the business environment and finally the cooperation with the international development partners; for the purpose of embracing the entrepreneurial change through which the other countries such as Rwanda have succeeded in being a reference point for other countries. This can take the entrepreneurial development one step further if governance is applied and maintained to support the business environment. In addition to this, paying attention to the towards developing the essential skills among the youth, and develop skilled human capital which are also very essential for encouraging entrepreneurial perception and activities among the youth through education.

\section{CONFLICT OF INTEREST}

The authors report no conflict of interest in this study.

\section{FUNDING}

No funding was received for this study.

\section{REFERENCES}

Ács, Z. J., \& Virgill, N. (2009). Entrepreneurship in developing countries (No. 2009, 023). Jena economic research papers. http://hdl.handle.net/10419/31789

Acs, Z. J., Desai, S. and Hessels, J. (2008). Entrepreneurship, economic development and institutions, Small Business Economics, Vol. 31, 219-234. https://doi.org/10.1007/s11187-0089135-9

Acs, Z., Audretsch, D., \& Strom, R. (2009). Introduction: Why entrepreneurship matters. Entrepreneurship, growth, and public policy. Cambridge University Press, New York. https://doi.org/10.1017/CBO9780511805950.002

Afolayan, E. (2015, 24 January). Rwanda tops the UN Human Development Index, http://africa-me.com/rwanda-tops-the-un-human-development-index/ Acessed: 15/10/2019

Ahmed, M. U. (2015). Entrepreneurship and economic Development: A Discourse on selected conceptual issues, Daffodil International University Journal of Business and Economics, Vol. 9(1), PP.187-193. URI: http://hdl.handle.net/20.500.11948/1400

Aidis, R., Estrin, S., \& Mickiewicz, T. M. (2007). Entrepreneurship in Emerging Markets: Which Institutions Matter?, Working paper (No. 81). UCL School of Slavonic and East European Studies (SSEES). https://econpapers.repec.org/paper/seewpaper/81.htm

Aliriani, K. (2013). Role of SMEs in the Economy: The Case of Yemen, proceeding of: Yemen: Challenges for the Future, International Conference, London, January 11\&12, 2013.

Alnedhari, M. (2009). Nature of small and smaller enterprises in Taiz Governorate, Proceedings of the sub conference of local administration, 10 - 11 June 2009, Taiz, pp. 37-52.

Alsabai, S. A. A. (2011). Small enterprises in Yemen and the funding role of MFIs, Modern Administrative Journal, Vol. 6 (1), 35-68.

Assaf, N. (2013). Stimulating business and employment in Yemen. MENA Knowledge and Learning Quick Notes Series, No. 91, World Bank Group, Washington, DC. http://hdl.handle.net/10986/16127

Audretsch, D. B. (2009). Emergence of the entrepreneurial society. Business Horizons, 52(5), 505-511. https://doi.org/10.1016/j.bushor.2009.06.002

Austin, G., Dávila, C., \& Jones, G. G. (2017). Emerging markets and the future of business history. Harvard Business School General Management Unit Working Paper, (18-012). http://dx.doi.org/10.2139/ssrn.3012606

Baumol, W. J. (1990), Entrepreneurship: Productive, unproductive and destructive, Journal of Political Economy, Vol. 98 (5), 893-921. https://doi.org/10.1016/0883-9026(94)00014-X

Baumol, W. J. (1993). Formal entrepreneurship theory in economics: Existence and 
bounds. Journal of business venturing, 8(3), 197-210. https://doi.org/10.1016/08839026(93)90027-3

Blimpo, M. P., \& Pugatch, T. (2019). Entrepreneurship education and teacher training in

Rwanda. Journal of Development Economics, 140,

186-202. https://doi.org/10.1016/j.jdeveco.2019.05.006

Brixiova, Z. (2010). Unlocking productive entrepreneurship in Africa's least developed countries. African Development Review, 22(3), 440-451. https://doi.org/10.1111/j.1467$\underline{\text { 8268.2010.00255.x }}$

Bruton, G. D., Ahlstrom, D., \& Obloj, K. (2008). Entrepreneurship in emerging economies: Where are we today and where should the research go in the future. Entrepreneurship theory and practice, 32(1), 1-14. https://doi.org/10.1111/j.1540-6520.2007.00213.x

CIA, (2018). The World FactBook 2018, Central Intelligence Agency, Government Printing Office. ISBN13: 9781510740273

Coffey, (2014). Scoping the Need for Improved Access to Funding, Advisory Support and Business Skills Development for SMEs in Afghanistan, Coffey International Development Ltd. UK.

CSO , (2018). The Afghanistan Population Estimates for the year 1397 (2018 -19), Central Statistics Organization, Kabul.

CSO, (2005). Statistical Year Book, Central Statistical Organization, Sana'a, Yemen.

CSO, (2017). Statistical year Book 2017, Central Statistical Organization, Sana'a, Yemen

Eltahir, O. (2018). Factors affecting the performance \& business success of small \& medium enterprises in sudan (Case study: Omdurman). International Journal of Small Business and Entrepreneurship Research, 6(6), 14-22.

Georgieva, K. (2018). The future drivers of growth in Rwanda, retrieved from: https://blogs.worldbank.org/nasikiliza/the-future-drivers-of-growth-in-rwanda , Accessed: 14/01/2020.

GOB, (2016). Bangladesh Industrial policy 2016, Government of Bangladesh, Dhaka.

Golooba-Mutebi, F. (2008). Collapse, war and reconstruction in Rwanda: an analytical narrative on state-making (pp. 1-40). London: Crisis States Research Centre.

Government of Rwanda, (2000). Rwanda Vision 2020, Kigali.

Government of Rwanda, (2002). Poverty Reduction Strategy Paper 2002, Kigali.

Government of Rwanda, (2007). Economic Development and Poverty Reduction Strategy, 2008-2012, Kigali.

Government of Rwanda, (2013). Economic Development and Poverty Reduction Strategy II, 2013-2018, Kigali.

Habyarimana, J. B., \& Dushimayezu, B. (2018). Good Governance, Economic Growth and Development: Insights from a 22-Year Econometric Analysis in Rwanda. Rwanda Handbook of Economic and Social Policy. Kigali, ISBN 978-91-86345-78-5

Kagame, P. (2014). Keynote address by President Kagame. Speech delivered on the 20th anniversary of the genocide, Kigali, https://www.youtube.com/watch?v=oprDR1-DQEg

Kumar, K., Tardif-Douglin, D. G., Knapp, C., Maynard, K., Manikas, P., \& Sheckler, A. (1996). Rebuilding postwar Rwanda: The role of the international community. Center for Development and Evaluation, US Agency for International Development. Kigali, Rwanda.

Mashal, M. (2014). Small and medium enterprises development and regional trade in Afghanistan. Institute of Public Policy and Administration Working Paper, (24). http://dx.doi.org/10.2139/ssrn.2943895

Minicom, (2010). SMEs product clusters in Rwanda booklet, Kigali.

Minicom, (2010a). Small and Medium Enterprises (SMEs) Development Policy, Kigali.

Ngabonziza, D. (2015, July $7^{\text {th }}$ ). Rwanda Education Success Story Applicable To Developing Countries, https://www.ktpress.rw/2015/07/rwanda-education-success-story-applicable-todeveloping-countries/ Accessed 15\12\2019.

National Institute of Statistics of Rwanda, (2015). Establishments census 2014, National Institute of Statistics of Rwanda. Kigali, Rwanda.

Nsengimana, S. (2017). Challenges to women entrepreneurship in Kigali, Rwanda, Master's Dissertation, Cape Peninsula University of Technology. http://hdl.handle.net/20.500.11838/2589 
Obura, A. P. (2003). Never again: Educational reconstruction in Rwanda. International Institute for Educational Planning. https://doi.org/10.1093/refuge/fei026

PSDP.(2011). National Micro, Small \& Medium Sized Enterprise Development Strategy for Yemen - 2011-2021, Private Sector Development Project (PSDP), Yemen.

Reynolds, P. D., Bygrave, W. D., \& Autio, E. (2003). Global entrepreneurship monitor: 2003 executive report. Babson College. https://www.gemconsortium.org/report/gem-2003-globalreport (Accessed: 14/01/2020).

Saleh, M. A. K., \& Manjunath, K. R. (2020). Review of Historical and Temporary Challenges Facing Small and Medium Enterprises in Yemen. International Journal of Trend in Scientific Research and Development, Vol. 4(3), pp. 752-764.

Saleh, M. A. K., \& Manjunath, K. R. (2020a). Enterprising under political and economic instability in Least Developing Countries: challenges and prospects - case study of Yemen. in: Business Trends: Issues and Implications, pp. 23-30. Excel India Publishers, New Delhi.

Saleh, M., Manjunath, K. R., \& Oaied, M. M. (2021). Exploring entrepreneurial attitudes among youth in least developed countries: Empirical evidence from Yemen. FOCUS: Journal of International Business, 8(1), 71-99. https://doi.org/10.17492/jpi.focus.v8i1.812104

Saleh, M. A. K., \& Manjunath, K. R. (2020b). Exploring Essential Enterprising Skills among Youth in Least Developed Countries: Empirical Insight from Yemen. PIMT Journal of Research, 13(1). pp. $153-157$.

Saleh, M. A. K., \& Manjunath, K. R. (2021a). Entrepreneurship perception among the youth in underdeveloped economies: Perspective of Yemen, SJCC Management Research Review, Vol. 11(1), pp. 65 - 48. DOI: 1035737sjccmrr/v11/i1/2021165526

Saqr, A. M. K. (2019). Small Enterprises: The Idea and the execution method, Dar Etalem Elgame, Alexandria, Egypt.

Siddiqui, M. S. (2014). Small \& Medium Enterprises, Access to Finance, Export Promotion Potential and Formalization, Ministry of Commerce \& Industries, Islamic Republic of Afghanistan.

Smallbone, D., Welter, F., \& Ateljevic, J. (2014). Entrepreneurship in emerging market economies: Contemporary issues and perspectives. International Small Business Journal, 32(2), 113-116. https://doi.org/10.1177/0266242613511479

Switch-Asia, (2017). Green Finance for SMEs in Afghanistan, retrieved from: https://www.switchasia.eu/fileadmin/user_upload/Publications/infographics/Compilations/Infographics_Green_F inance_komplett.pdf (Accessed: 22/01/2020)

Taka, M. (2020). The role of education in peacebuilding: learner narratives from Rwanda. Journal of Peace Education, 17(1), 107-122. https://doi.org/10.1080/17400201.2019.1669146

United Nations, (2019). The Least Developed Countries Report 2019, United Nations Publications, New York. eISBN: 978-92-1-004377-9

Volery, T., \& Mazzarol, T. (2015). The evolution of the small business and entrepreneurship field: A bibliometric investigation of articles published in the International Small Business Journal. International Small Business Journal, 33(4), 374-396. https://doi.org/10.1177/0266242613516139

World Bank, (2008). Doing business 2009, The World Bank, Washington, DC. https://doi.org/10.1596/978-0-8213-7609-6

World Bank, (2009). Doing business 2010: Reforming through difficult times, The World Bank, Washington, DC. https://doi.org/10.1596/978-0-8213-7961-5

World Bank, (2010). Doing business 2011: Making a difference for entrepreneurs, The World Bank, Washington, DC. https://doi.org/10.1596/978-0-8213-7960-8

World Bank, (2011). Doing business 2012: Doing business in a more transparent The world, World Bank, Washington, DC. https://doi.org/10.1596/978-0-8213-8833-4

World Bank, (2012). Doing business 2013: Smarter regulations for Small and Medium-size enterprises, The World Bank, Washington, DC. https://doi.org/10.1596/978-0-8213-9615-5

World Bank,(2013). Doing business 2014:Understanding regulations for small and mediumsize enterprises, The World Bank, Washington, DC. https://doi.org/10.1596/978-0-8213-99842

World Bank, (2014). Doing business 2015: Going beyond efficiency, The World Bank, 
Washington, DC. https://doi.org/10.1596/978-1-4648-0351-2

World Bank, (2015). Doing business 2016: Measuring Regulatory Quality and Efficiency, The World Bank, Washington, DC https://doi.org/10.1596/978-1-4648-0667-4

World Bank, (2015a). Yemen, Republic of - Unlocking the potential for economic growth, World Bank Group, Washington, D.C. http://hdl.handle.net/10986/23660

World Bank, (2016). Doing business 2017: Equal Opportunity for All, The World Bank, Washington, DC. https://doi.org/10.1596/978-1-4648-0948-4

World Bank, (2017). Doing business 2018: Reforming to Create Jobs, The World Bank, Washington, DC.

World Bank, (2018). Doing business 2019: Training for reform, The World Bank, Washington, DC. 